\title{
Analysis of Seasonal Behavior, Cycle Occurrences and Price Trends of Brazil nut Products Exported from Brazil
}

\author{
Lorena Figueira de Santana $^{1}$, Thiago Manoel Sozinho ${ }^{1}$, João Carlos Garzel Leodoro da Silva ${ }^{2}$, José Roberto Frega ${ }^{3}$, \\ Lauro Brito de Almeida ${ }^{4} \&$ Jaqueline Valerius ${ }^{1}$ \\ ${ }^{1}$ School of Forestry Engineer, Postgraduate Student, University of Parana, Curitiba, Brazil \\ ${ }^{2}$ School of Forestry Engineer, Holder Professor, University of Parana, Curitiba, Brazil \\ ${ }^{3}$ School of Applied Social Sciences, Assistant Professor, University of Parana, Curitiba, Brazil \\ ${ }^{4}$ School of Accounting, Associate Professor III, University of Parana, Curitiba, Brazil \\ Correspondence: João Carlos Garzel Leodoro da Silva, School of Forestry Engineer, University of Parana, \\ Curitiba, Brazil. Tel: 55-(41)-9118-6332. E-mail: garzel@ufpr.br
}

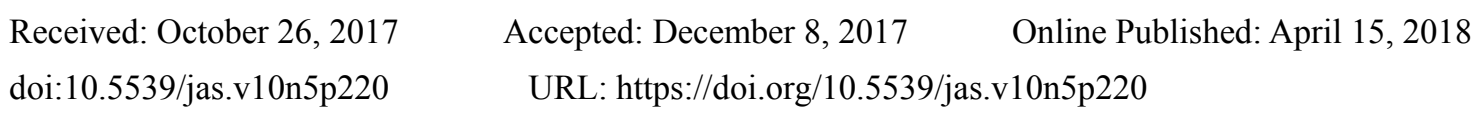

The research is financed by CAPES and FUNPAR.

\begin{abstract}
The exploitation of non-timber forest products (NTFPs) represent a way of subsistence for Amazon extractive communities, which demonstrate great recognition of its importance to income generation, notably in rural areas. This paper aims to identify and analyze the existence of seasonal behavior, cycle occurrence and price tendency upon Brazil nuts products (Bertholletia excelsa H.B.K.) exported by Brazil to international market during 2005 to 2015. Products quantity and price database were collected from Foreign Trade Information Analysis System (AliceWeb) and used as proxy to estimate its unit price in US\$ $/ \mathrm{kg}$. Deflated by the Consumer Price Index (CPI), using as reference base December 2015, the analysis consisted on applying the Mobile Geometric Mean (MGM) and the ARIMA econometric models. The evaluation of cycles and tendency were realized by graphic analysis of the stationary indexes, visual identification of structural series breaks and plotting reference value to analyze the occurrence of increase or decrease price. Because of the models application a seasonal price behavior was observed for both Brazil nuts products analyzed, shelled and in shell. Although the tendency of price growth was verified for both, the in shell products presented short term annual cycles, while for the shelled product only three long term cycles with distinct intervals were noticed.
\end{abstract}

Keywords: ARIMA, non-timber forest products (NFTPs), Amazon

\section{Introduction}

The exploitation of non-timber forest products (NTFPs) is a means of subsistence for extractive communities that contribute to the maintenance of the structure and functionality of native forests, and the systems of exploitation of products inserted in a context of numerous social, political and economic relations (Santos, Hildebrand, Pacheco, Pires, \& Rochadelli, 2003; Balzon, Silva, \& Santos, 2004; Hernández-Barrios, Anten, \& Martínez-Ramos, 2015; Tieguhong, 2015; Elias \& Santos, 2016; Ball \& Brancalion, 2016).

Thus, considering the premise of the extraction of these products, NTFPs can be defined as the different plant and animal products obtained in forest environments and extracted from natural forests, as well as in plantations, agroforestry systems, or produced in varying degrees of domestication. Therefore, coconut, rubber and cocoa can represent examples of NTFP (Wong, Thornber, \& Baker, 2001; Vantomme, 2001; Santos et al., 2003).

However, considering the extent of this concept due to lack of adequate knowledge of these products, the absence of adjusted development practices and policies, or even product diversity, there is no universally accepted concept by researchers and institutions. Among the existing currents of thought, the common point is the non-admission of timber as an NTFP independent of destination (Alves, 2010).

Extractive activities associated with NTFP exploitation, particularly in the Amazon, are linked to the difficulty of access to the areas where they occur in abundance, which is also one of the barriers to commercialization of 
these products extracted on a large scale, but without adding value. The lack of strategies to differentiate these products limits the contribution of the activity to regional social, economic and environmental development (Gama, 2016).

Although domestication of species has intensified throughout world history, and in Brazil more and more farmers are adopting crop regimes of species, some of them have not been domesticated so far, for example Brazil nut (Bertholletia excelsa H.B.K.) (Veasey et al., 2011). This, considered of great importance for many riverside communities of the Amazon region, still does not have an economically feasible plantation model and its exploitation is carried out solely by the extractivism in the forest areas, located in the Amazon region, mainly in the states of Amazonas, Pará, Acre and Rondônia (Homma, 2001, 2006; Pimentel, 2007).

The growing recognition of the importance and contribution of non-timber forest products in socioeconomic and environmental aspects has attracted the global interest for these products, since they play an important role in income generation, especially in rural areas (Elias \& Santos, 2016; Maisharou \& Larwanou, 2015).

Although the national scientific literature presents a lack of studies on the temporal analysis of NTFPs price series, some products have several papers with other approaches. Thus, Gonçalo (2006) discussed integrated strategies for the best management and commercialization of NTFP of Brazil's biodiversity; Salomão (2009) assessed the density and spatial distribution of Brazil nut trees (Bertholletia excelsa H.\&B.) in northern Brazilian Amazon and Assis (2011) made a comparative analysis between small farms in Brazil and India concerning the relation among their extractive activities and management to biodiversity conservation in situ.

Similarly, other authors evaluated economic and market subjects regarding NTFP's. Seasonality assess of retail prices of açaí, cupuaçu and bacaba in Pará is discussed on Nogueira and de Santana (2011); Lopes, Almeida, and dos Santos (2006) evaluated the seasonality, production cycles and prices of açaí marketed in the city of Belém between 1995 and 2004. Both studies perceived a strong seasonal component and defined price cycles periods for the products analyzed.

The concerns regarding NTFP can be found with broader discussions globally, as Albers and Robinson (2013) who reviewed the spatial economics of NTFP and its implications on policy. Likewise, Shaafsma et al. (2014) made the economic valuation of NTFP in eastern Arc Mountains in Tanzania and evaluated the local forest importance to low income families. Finally, Živojinović et al. (2017) analyzed NTFP in transition economies and innovation cases in selected southeast European countries where they found poor support for NTFP businesses and weak innovation systems, suggesting the urging need to give more importance to NTFP.

Thus, considering the economic, social and environmental importance of Brazil nut extraction for Amazon communities, this work aims to identify the existence of seasonal behavior, analyze the occurrence of cycles and the price trends of Brazil nuts - with rind and shelled — exported by the country during the period from 2005 to 2015.

\section{Method}

\subsection{Data Source}

The data used were extracted from the Foreign Trade Information Analysis System (AliceWeb), developed by the Foreign Trade Secretariat and the Ministry of Development (SECEX).

The information collected covers the years 2005 to 2015, and data on the value of exports (US\$) and quantities $(\mathrm{kg})$ of Brazil nut, with rind and shelled, were analyzed, according to the Mercosur Common Nomenclature (NCM) 8 digits, of which: 08012100 — Fresh or dried Brazil nut, with rind; and 08012200—Brazil nut, fresh or dried, shelled.

Similarly to Cardoso, Soares, Silva \& Timofeiczyk (2013), the unit price of Brazil nut exported as the ratio between the value of the production acquired by the foreign trade of these products (US\$) and the quantity produced for export $(\mathrm{Kg})$ was obtained, as follows on Equation 1:

$$
P_{u}=V / Q
$$

Where,

$P_{u}$ : unit price of product (US\$ $/ \mathrm{kg}$ ); $V$ : real gross export value (US\$); $Q$ : exported quantity of the product (t).

\subsection{Processing of Data}

The price analysis of a product involves several economic factors, which should be considered for the possibility of affecting medium and long term comparative analysis. With the possible distortions influenced by inflationary 
effects, the Consumer Price Index (CPI), having as the month and base year December 2015, deflated the prices of the evaluated products after the data collection and tabulation.

Time series, which are understood as a set of observations ordered in time to a dependent between the instants of time, hold stochastic characteristics and can be influenced by several factors (Granger \& Newbold, 2014; Box, Jenkins, Reinsel, \& Ljung, 2015). Therefore, four main components of the price are considered in the series that help to explain these influences: seasonality, trend, cycle and randomness (Pindyck \& Rubinfeld, 2005; Morentin $\&$ Toloi, 2006).

The general representation of the model is given by:

$$
X=S \times T \times C \times A
$$

Where,

$X=$ time series; $S=$ seasonal component; $T=$ trend component; $C=$ cyclic component; $A=$ randomness component.

Seasonality can be classified into two types with regard to knowing the reasons or not for the occurrence of an event that may influence the behavior of a series of prices. Thus, it can assume deterministic character in situations that are known the reasons for occurrence of the event and stochastic, when there is no knowledge of the factors (Morentin \& Toloi, 2006).

\subsection{Analysis Methods}

Thus, assuming the stochastic nature of the factors influencing Brazil nut prices, the analysis of the price series data for the products contemplated in this study used the methodology of Mobile Geometric Mean (Gt), cited by Hoffman (2006), and Bouzada (2012), where three price components are considered:

i) $A B^{t}$, Factor that includes the trend and variations in the level of prices between the years;

ii) $\varepsilon_{j}$, Representative factor of seasonal variations;

iii) $U_{t}$, Random variations in monthly prices.

Demonstrated on Equation 3:

$$
P_{t}=P_{i j}=A B^{t} \cdot \varepsilon_{j} \cdot U_{t}
$$

Where,

$P=$ product price; $i=$ indication of the year; $j=$ indication of the month.

The seasonality calculation steps are broken down:

a) Centralized Mobile Geometric Mean

$$
g_{t}=1 / 12\left(0.5 \cdot \ln P_{t-6}+\ln P_{t-5}+\ldots+\ln P_{t}+\ldots+\ln P_{t+5}+\ln P_{t+6}\right)
$$

Where,

$g_{t}=\ln G_{t}=$ Geometric moving mean of month $\mathrm{t} ; P_{t}=$ price at month $t ; t=$ month the mean is centralized.

b) Seasonal Price Index

$$
I_{t}=\left(\frac{P_{t}}{G_{t}}\right) \times 100
$$

Where,

$I_{t}=$ Seasonal index in month $t ; P_{t}=$ price in the month $\mathrm{t} ; G_{t}=$ geometric mean in month $t$.

c) Monthly Seasonal Index

$$
\ln \bar{I}_{i}=\frac{1}{m-1} \sum_{j}^{m} \ln _{i j}
$$

Where,

$i=$ month (January, February, $\ldots$ December); $j=$ year; $m=$ number of years.

d) Irregularity Index

Where,

$$
s_{i}=\sqrt{\frac{1}{m-2} \sum_{j=1}^{m-1}\left(d_{i j}-\bar{d}_{i j}\right)^{2}}
$$

$i=$ month (January, February, $\ldots$ December); $j=$ year; $m=$ number of years. 
The analysis of seasonality of product prices also used the application of ARIMA auto regressive models, which used models with averages of short and long-term lags to analyze the influence of the last two months and last two years, respectively, on prices of the products analyzed. Finally, to choose the best-adjusted model, the Akaike Information Criterion (AIC) was applied.

The evaluation and determination of price cycles used the graphical plotting of the unit price data, which allowed the analysis of the variation of these in relation to the average values. Also, allowed the division of the period in question in cycles from the series break, due to abrupt price declines, also verified by the application of the Chow test in the temporal series of the nut products.

Finally, to analyze the trend of prices, a regression of the unit prices of the nut products was used during the evaluated period.

\section{Results}

\subsection{Analysis of Seasonality of Prices}

The seasonal and irregular variations of both Brazil nut products analyzed can be observed in Figure 1.

The product with rind (Figure 1a) presented greater instability in the seasonality curve. For this product, the price tends to be lower in the months of January and February increasing significantly in the months until June. Subsequently, prices fell in the months that followed, when prices rebound steeply - in relation to the previous month - in October, and then suffer another reduction. This being the month with the highest price variation, which can be observed by the behavior of the positive and negative error rates in this period.

In contrast, the seasonality curve of the shelled product (Figure $1 \mathrm{~b}$ ) showed stability and little price oscillation during the year. Yet, in the first two months of the first semester, it is lower than in the second half of the year, which is indicative of seasonal behavior.

Despite this, it is observed that throughout the period there is a great variation of the prices in the analyzed years, indicated by the inconstancy of the irregularity index curves.

The application of ARIMA models to evaluate the seasonality of prices indicated values with significance for the short and long-term lags in relation to the prices of the product with rind and presence of seasonality only for the short term lag in relation to the values of the shelled product. Therefore, this did not show seasonality of prices in relation to the previous two years.
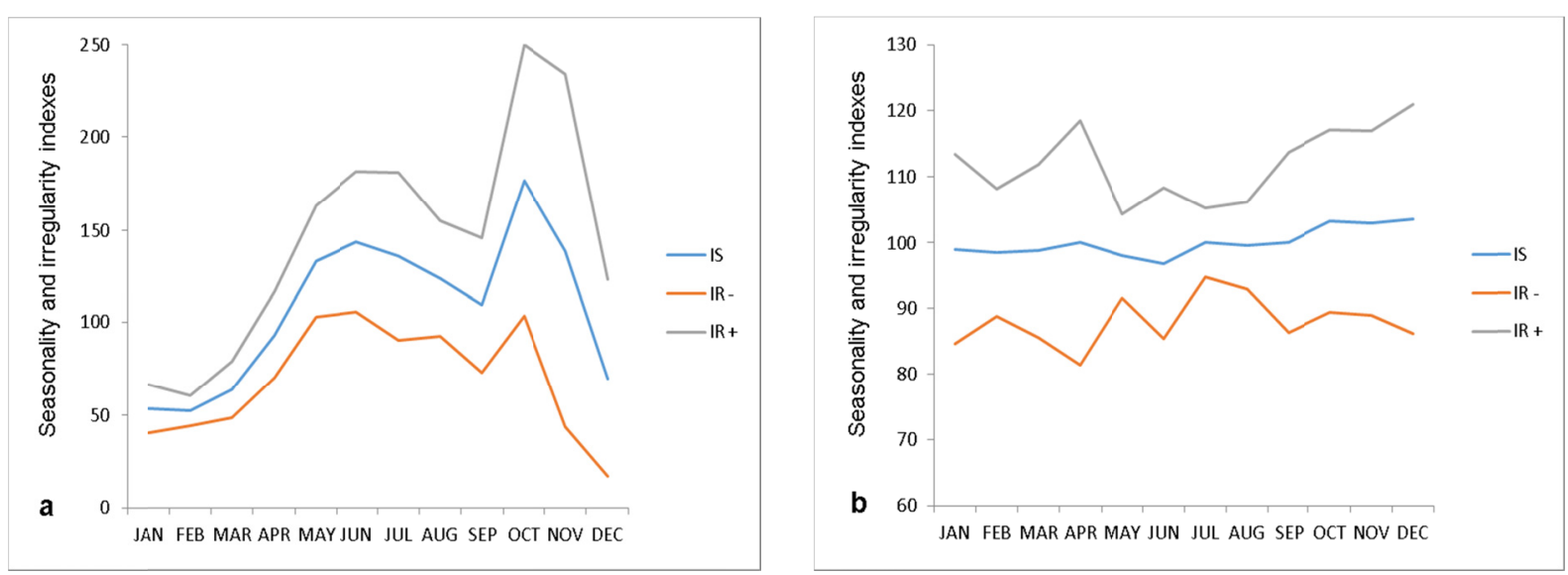

Figure 1. Seasonality and irregularity indexes of Brazil nuts exported by Brazil during 2005 to 2015 (a-"in rind" and b-"shelled")

The AIC values recorded for the models used were 217.22 and 243.33 , respectively, for the product with rind and the shelled one. 
Table 1. AIC values registered for the models applied related to each product

\begin{tabular}{lllll}
\hline Product & P-value (last month) & P-value (monthly delay) & P-value (year delay) & Akaike Criteria (AIC) \\
\hline Brazil nut with rind & $4.83 \times 10^{-11} * * *$ & $0.0195^{* *}$ & $1.19 \times 10^{-23 * * *}$ & 217.22 \\
Shelled Brazil nut & $3.62 \times 10^{-162 * * *}$ & 0.3529 & & \\
\hline
\end{tabular}

Note. $* * *$ Significance level of $1 \%$; ** Significance level of $5 \%$.

The behavior of the price of a product over time represents information of extreme importance for the agents that intend to carry out a commercial transaction, as it acts as an indicator for them about the optimal moment of acquiring and / or selling the product, based on the best price criterion.

From the standpoint of the importer, the prices of the product with rind are lower in the first and last months of the year, since the shelled product does not present a significant reduction of prices between the semesters, despite the instability of the irregularity curves reflecting the amplitude of the variation of prices.

Even though, from the point of view of the producer, there is a willingness to sell their products for higher prices, there is also a risk attached to the non-commercialization of products due lower price because of the Brazil nuts perishability.

\subsection{Analysis of Cycle and Price Trends}

The extractive activity of Brazil nuts depends on the regular collection of the product, which can be influenced by climatic factors such as the rainfall regime, which directly reflects the market dynamics of the product.

The behavior of the product with rind reflects the dynamics of exploitation of the species, which usually occurs between the months of December and June. Thus, the price of the product tends to increase in the final months of collection and in most of the off-season (Figure 2-a).
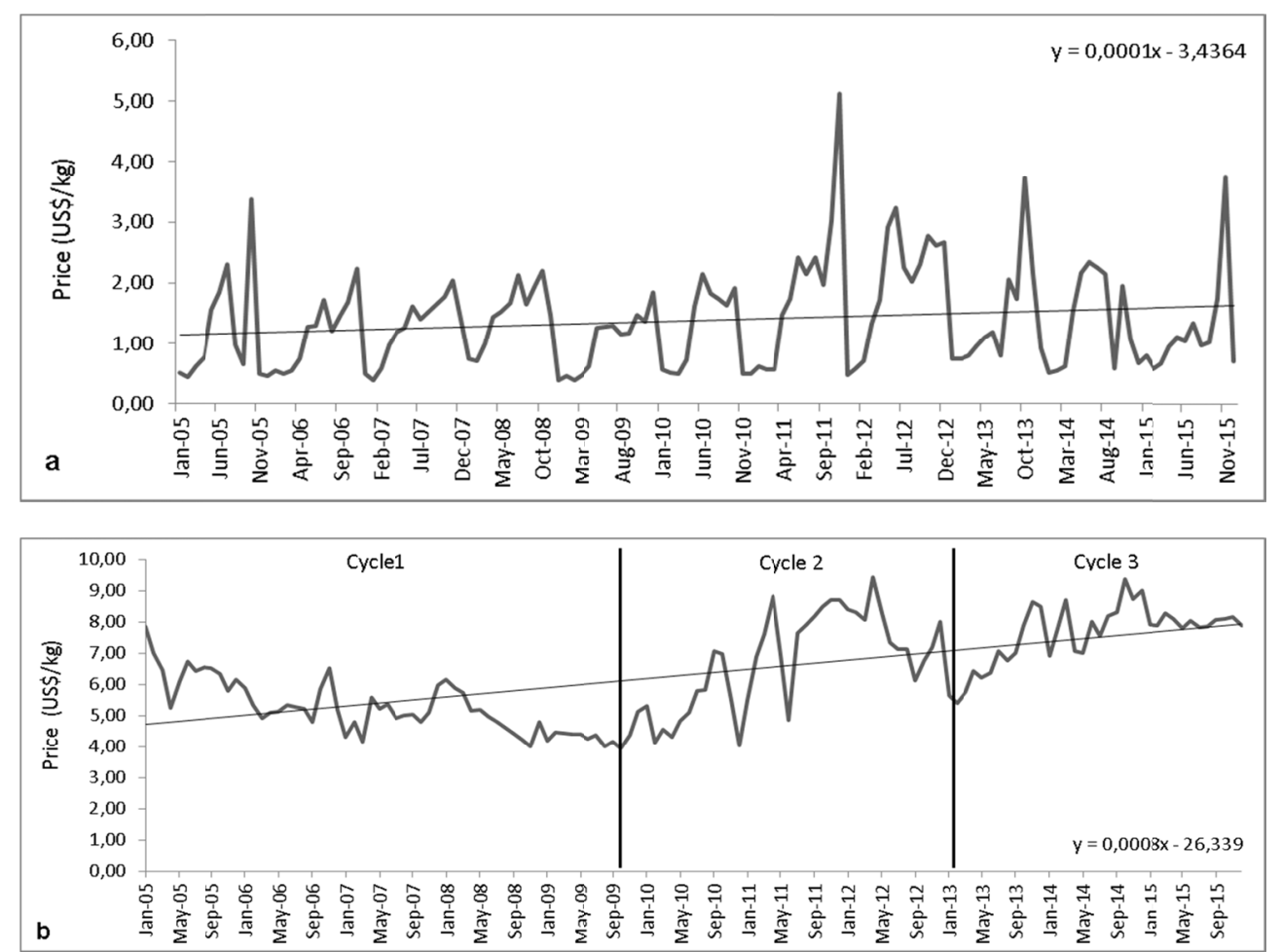

Figure 2. Variation and trend of the unit price (us $\$ / \mathrm{kg}$ ) of the Brazil nut products, a-with rind and b-shelled, exported by Brazil to the world between the months of January 2005 and December 2015

During the period analyzed, from 2005 to 2015, the prices of this product fluctuated significantly, in accordance with the natural cycle of exploration and without occurrence of moments that stood out in long cycles. 
The maximum and minimum prices recorded in the period were in November 2011 and December 2008, respectively, with values of US\$ $5.11 / \mathrm{kg}$ and US\$ $0.38 / \mathrm{kg}$.

That way, it is possible to infer from the behavior of the price curve that there was a gradual increase in the price of the product with rind during the analyzed period and it is possible that this growth will continue for the next years.

The price of the product without rind (Figure 2-b), exported by Brazil, presented high instability during the period evaluated, emphasizing the presence of three cycles of distinct intervals.

The first cycle lasted 57 months, starting in January 2005 until September 2009; already the second cycle lasted 41 months, between October 2009 and February 2013; and, finally, the third cycle with a duration of 34 months, starting in March 2013 until December 2015. However, it should be noticed that this might still be expanding.

The instability in the price of the product exported along almost five years is observed in cycle 1, with a decreasing price behavior assuming an average of US\$ $5.30 / \mathrm{kg}$. Nevertheless, at the end of this cycle there is a price increase already in October 2009.

Prices fluctuated significantly during the second cycle at short intervals: US\$ 4.00/kg in December 2010; US\$ 6.90/kg in February 2011; US\$ 8.80/kg in April 2011; US\$ 4.85/kg in June 2011 and US\$ 7.60/kg in July 2011. Finally, the price reached a peak during the cycle in April 2012 (US\$ 9.40/kg) followed by a few oscillations until reach US\$ 5.40/kg in February 2013.

Finally, the third cycle is characterized by the increase of the shelled product price, ranging from US\$ 7.0/kg to US\$ $9.0 / \mathrm{kg}$ by the end of the series in December 2015, registering US\$7.9/kg.

Therefore, the analysis of the trend line of the prices of the product without rind indicates the gradual increase of these in the long term, suggesting the continuity of the increasing behavior for the following months.

\subsection{Seasonal Variation of Product Prices}

The seasonal variation of prices of the product with rind, presented in Figure 3-a, showed similar behavior to the price curve, with the maximum and minimum values recorded in October 2005 (353.93) and December 2011 (30.24).

The seasonal analysis of prices for the shelled product, Figure 3-b, showed a smaller variation in the indexes over the analyzed period, as the first cycle presented a coefficient of variation (CV) of $16.33 \%$, with the maximum and minimum values of the seasonal indexes presented in April 2005 (91.84) and November 2006 (145.96), respectively. 

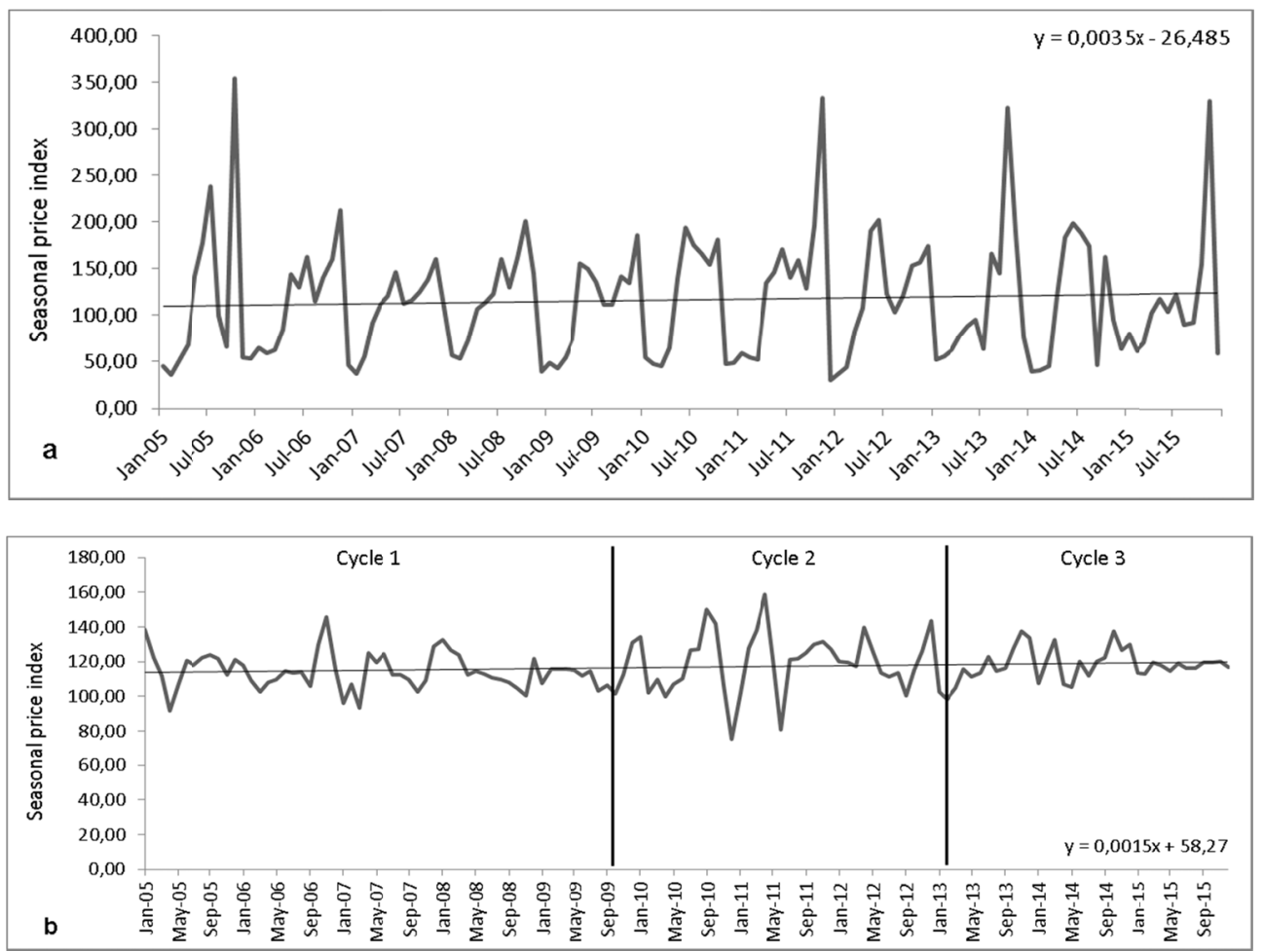

Figure 3. Seasonal price index (us $\$ / \mathrm{kg}$ ) of Brazil nut, a-with rind; $b$-shelled, exported by Brazil between the months of January 2005 and December 2015

The maximum and minimum values were recorded, both in the second cycle, in the months of April 2011 (158.7) and December 2010 (75.43), respectively. Thus, the high CV (23.93\%) found during this cycle indicates the possibility of relevant occurrences that affected the prices practiced in this sub period.

The third and last cycle presented the lowest CV (10.70\%). Thus, it represents a cycle marked by greater stability, despite having higher and lower indexes distant from each other in the first months of the time series, such as 107.80 in February 2014 and 132.85 in March 2014. That way, it is emphasized again the possibility of this cycle not having finished, being able to present different behavior in relation to the previous data.

\section{Conclusions}

$>$ The product that indicated a seasonal behavior by the interpretation of the seasonality curve by the ARIMA method were the Brazil nuts with bark, while the shelled Brazil nut showed a seasonal behavior only by the interpretation of the curve of seasonality;

The price of Brazil nuts with rind presented short-term (annual) cycles, as reflected by the dynamics of the species' extractivism, while the price of shelled Brazil nut presented three long-term cycles. Both seasonal indexes of the products presented the same behavior;

$>$ There is an increasing price trend for all products analyzed.

\section{References}

Albers, H. J., \& Robinson, E. J. Z. (2013). A review of the spatial economics of non-timber forest product extraction: Implications for policy. Ecological Economics, 92, 87-95. https://doi.org/10.1016/j.ecolecon. 2012.01.021

AliceWeb. (2015). Sistema de Análise das Informações de Comércio Exterior. Retrieved December 1, 2015, from http://www.aliceweb.desenvolvimento.gov.br

Alves Elias, G., \& dos Santos, R. (2016). Produtos florestais não madeireiros e valor potencial de exploração sustentável da floresta atlântica no sul de Santa Catarina. Ciência Florestal, 26(1). https://doi.org/ $10.5902 / 1980509821117$ 
Alves, R. V. (2010). Estudo de caso da comercialização dos produtos florestais não madeireiros (PFNM) como subsídio para a restauração florestal.

Anefalos, L. C., Moreira, S. R., Cipolli, K. M. V. A. B., Turco, P. H. N., \& Tavares, P. E. D. R. (2008). Sazonalidade da Oferta de Produtos Hortícolas: O Mercado de Berinjela. In 46th Congress, July 20-23, 2008, Sociedade Brasileira de Economia, Administracao e Sociologia Rural (SOBER), Rio Branco, Acre, Brasil (No. 113377).

Araújo, A., Midjei, R., \& Santos, A. (2012). Estudo do comportamento e sazonalidade do preço do cacau no Estado da Bahia. In III Congresso Brasileiro do Cacau, Ilhéus, Bahia.

Assis, A. L. A. D. A. (2011). Manejo comunitário da biodiversidade, empoderamento e conservação in situ: Uma comparação de estudos de caso no Brasil e na Índia. UFSC.

Ball, A. A., \& Brancalion, P. H. (2016). Governance challenges for commercial exploitation of a non-timber forest product by marginalized rural communities. Environmental Conservation, 43(3), 208-220. https://doi.org/10.1017/S0376892916000072

Balzon, D. R., da Silva, J. C. G. L., \& dos Santos, A. J. (2004). Aspectos Mercadológicos de Produtos Florestais Não Madeireiros Análise Retrospectiva. Floresta, 34(3). https://doi.org/10.5380/rf.v34i3.2422

Bouzada, M. A. C. (2012). Aprendendo Decomposição Clássica: Tutorial para um Método de Análise de Séries Temporais. Tecnologias de Administração e Contabilidade, 2(1), 1-18. https://doi.org/10.21714/ 2236-02632012v2n1tac14

Box, G. E., Jenkins, G. M., Reinsel, G. C., \& Ljung, G. M. (2015). Time series analysis: Forecasting and control. John Wiley \& Sons.

Cardoso, M. V., Soares, P. R. C., Silva, J. C. G. L. D., \& Timofeiczyk Junior, R. (2013). Estudo da sazonalidade do preço da celulose brasileira no mercado dos Estados Unidos em periodos cíclicos como apoio a estratégias empresariais.

Da Silva Neto, W. A., Pinheiro, M. A., Parre, J. L., \& Alves, A. F. (2006). Sazonalidade, margem de comercialização e transmissão de preços do tomate de mesa no estado de São Paulo. In 44th Congress, July 23-27, 2006, Sociedade Brasileira de Economia, Administracao e Sociologia Rural (SOBER), Fortaleza, Ceará, Brazil (No. 147306).

Gama, M. D. M. B. (2016). Principais relações de comercialização de Produtos Florestais Não Madereiros (PFNM) na Amazônia. Embrapa Rondônia-Artigo de divulgação na mídia (INFOTECA-E). Retrieved June, 2016, from http://www.agronline.com.br/artigos/artigo.php?id=299

Gonçalo, J. E. (2006). Gestão e comercialização de produtos florestais não madeireiros (pfnm) da biodiversidade no Brasil.

Granger, C. W. J., \& Newbold, P. (2014). Forecasting economic time series. Academic Press.

Hernández-Barrios, J. C., Anten, N. P., \& Martínez-Ramos, M. (2015). Sustainable harvesting of non-timber forest products based on ecological and economic criteria. Journal of Applied Ecology, 52(2), 389-401. https://doi.org/10.1111/1365-2664.12384

Hoffmann, R. (2006). Estatística para Economista. In P. Thomson (Ed.), Revista e ampliada. São Paulo, SP.

Homma, A. (2001). Viabilidade econômica da extração de produtos florestais não madeiráveis (pp. 01-17). Embrapa Amazônia Oriental, Belém.

Homma, A., Nicoli, C., de Menezes, A. J. E. A., de Matos, G. B., de Carvalho, J. E. U., \& Nogueira, O. (2006). Custo operacional de açaizeiro irrigado no Nordeste paraense. Embrapa Amazônia Oriental-Documentos (INFOTECA-E).

Lamounier, W. M. (2007). Tendência, ciclos e sazonalidade nos preços spot do café brasileiro na NYBOT. Gestão \& Produção, São Carlos, 14(1), 13-23. https://doi.org/10.1590/S0104-530X2007000100003

Lopes, M., Almeida, R., \& dos Santos, M. (2006). Sazonalidade e ciclos da produção de açaí comercializado no município de Belém no periodo de 1995 a 2004 (pp. 23-27). In XLIV Congresso da Sociedade Brasileira de Economia, Administração e Sociologia Rural, Fortaleza, Brazil.

Maisharou, A., \& Larwanou, M. (2015). Market potential of non-wood forest products in the Sahelian countries. International Forestry Review, 17(3), 125-135. https://doi.org/10.1505/146554815816007018 
Mendes, F., \& Lima, E. (2011). Sinopse do mercado de cacau em 2011. Informativo Técnico (No. 05. pp. 01-02). CEPLAC, Belém, Pará.

Morettin, P. A., \& Toloi, C. (2006). Análise de séries temporais. Blucher.

Nogueira, A. K. M., \& de Santana, A. C. (2011). Análise de sazonalidade de preços de varejo de açaí, cupuaçu e bacaba no estado do Pará. Revista de Estudos Sociais, 11(21), 7-22.

Pimentel, L. D., Wagner Junior, A., Santos, C. E. M., \& Bruckner, C. H. (2007). Estimativa de viabilidade econômica no cultivo da castanha-do-Brasil. Informações Econômicas, 37(6), 26-36.

Pindyck, R. S., \& Rubinfeld, D. L. (2005). Microeconomics (5th ed.). Prentice Hall.

Salomão, R. D. P. (2009). Densidade, estrutura e distribuição espacial de castanheira-do-brasil (Bertholletia excelsa H.\&B.) em dois platôs de floresta ombrófila densa na Amazônia setentrional brasileira. Boletim do Museu Paraense Emilio Goeldi Ciências Naturais, 4(1), 11-25. https://doi.org/10.5123/S1981-811420090 00100002

Santos, A. J. D., Hildebrand, E., Pacheco, C. H., Pires, P. D. T. D. L., \& Rochadelli, R. (2003). Produtos não madeireiros: Conceituação, classificação, valoração e mercados. Floresta, Curitiba, 33(2), 215-224. https://doi.org/10.5380/rf.v33i2.2275

Sato, G. S., Martins, V. A., \& Bueno, C. R. F. (2004). Sazonalidade dos Preços de Uva Fina Para Mesa no Estado de São Paulo.

Schaafsma, M., Morse-Jones, S., Posen, P., Swetnam, R. D., Balmford, A., Bateman, I. J., ... Geofrey, V. (2014). The importance of local forest benefits: Economic valuation of Non-Timber Forest Products in the Eastern Arc Mountains in Tanzania. Global Environmental Change, 24, 295-305. https://doi.org/10.1016/ j.gloenvcha.2013.08.018

Tieguhong, J. C., Ingram, V., Mala, W. A., Ndoye, O., \& Grouwels, S. (2015). How governance impacts non-timber forest product value chains in Cameroon. Forest Policy and Economics, 61, 1-10. https://doi.org/10.1016/j.forpol.2015.08.003

United States Department of Labor. (2015). Consumer Price Index (CPI). Bureau of Labor Statistics, US. Retrieved December 15, 2015, from http://www.bls.gov/cpi

Vantomme, P. (2001). Production and trade opportunities for non-wood forest products, particularly food products for niche markets. Geneva: FAO. Retrieved July, 2016, from http://www.fao.org/forestry/FOP/ FOPW/NWFP/nwfp-e.stm

Veasey, E. A., Piotto, F. A., Nascimento, W. F. D., Rodrigues, J. F., Mezette, T. F., Borges, A., ... Mistro, J. C. (2011). Evolutionary processes and the origin of crop plants. Ciencia Rural, 41(7), 1218-1228. https://doi.org/10.1590/S0103-84782011000700018

Wong, J. L. G., Thornber, K., \& Baker, N. (2001). Resource assessment of non-wood forest products: Experience and biometric principles (Vol. 13). Food \& Agriculture Org.

Živojinović, I., Nedeljković, J., Stojanovski, V., Japelj, A., Nonić, D., Weiss, G., \& Ludvig, A. (2017). Non-timber forest products in transition economies: Innovation cases in selected SEE countries. Forest Policy and Economics, 81, 18-29. https://doi.org/10.1016/j.forpol.2017.04.003

\section{Copyrights}

Copyright for this article is retained by the author(s), with first publication rights granted to the journal.

This is an open-access article distributed under the terms and conditions of the Creative Commons Attribution license (http://creativecommons.org/licenses/by/4.0/). 